\title{
PENGUATAN LITERASI ANAK MELALUI PROGRAM KELAS PENULIS CILIK
}

\author{
Umi Farkhatun \\ Institut Agama Islam Negeri Purwokerto
}

\begin{abstract}
The background of this research is the low interest in reading Indonesian students as one of the literacy skills. As an alternative solution to this, effective literacy improvement programs are needed for children. This study aims to determine the effectiveness of child writer's class program as a program to strengthen children's literacy. The subjects were 20 young writer class participants at PKBM Ar Rosyid. The method used in this research is descriptive qualitative. The results showed that the child writer's class was effective in strengthening children's literacy because through an interesting learning method, the program had succeeded in publishing two anthology books written by 67 young writers.
\end{abstract}

Keywords: Literacy, Young Writer, Child.

Abstrak. Latar belakang penelitian ini adalah rendahnya minat baca siswa Indonesia sebagai salah satu keterampilan dalam literasi. Sebagai alternatif solusi dari hal tersebut, diperlukan sebuah program penguatan literasi yang efektif bagi anakanak. Penelitian ini bertujuan untuk mengetahui efektivitas program kelas penulis cilik sebagai program penguatan literasi anak. Subjeknya adalah 20 peserta kelas penulis cilik di PKBM Ar Rosyid. Metode yang digunakan dalam penelitian ini adalah kualitatif deskriptif. Hasil penelitian menunjukkan kelas penulis cilik efektif dalam penguatan literasi anak-anak karena melalui metode pembelajaran yang menarik, program ini telah berhasil menerbitkan dua buah buku antologi yang ditulis oleh 67 penulis cilik.

Kata kunci: Literasi, Penulis Cilik, Anak.

\section{A. PENDAHULUAN}

Literasi memiliki beberapa komponen yang saling berkaitan yaitu literasi dasar (basic literacy), literasi perpustakaan (library literacy), literasi media (media literacy), literasi teknologi (technology literacy), dan literasi visual (visual literacy) dimana cakupan kemampuan dalam literasi dasar meliputi kemampuan untuk mendengarkan, kemampuan berbicara, kemampuan membaca, kemampuan menulis, dan kemampuan menghitung (Dikdasmen, 2016: 8-9). Kemampuan literasi dasar merupakan bagian dari keterampilan berbahasa dalam kurikulum sekolah (Tarigan, 2015 : 1). Hal tersebut dikuatkan oleh Safitri (2019: 154) yang menyatakan bahwa membaca menjadi salah satu keterampilan berbahasa yang memiliki peran penting dalam kehidupan berbahasa. Jika intensitas membaca rendah, maka keterampilan berbahasa yang lain seperti menulis, menyimak, berfikir kritis juga akan terpengaruh. Berdasarkan pemaparan tersebut dapat ditarik sebuah kesimpulan bahwa pengertian literasi adalah integrasi 
keterampilan menyimak, berbicara, menulis, membaca dan berpikir kritis (Priyatni, 2015: 40) dan inti dari literasi adalah kegiatan membaca, berpikir, kemudian menulis (Warsihna, 2016: 68).

Kemampuan literasi sangat dibutuhkan bagi manusia khususnya siswa di Indonesia sebagai generasi penerus bangsa. Tetapi kenyataannya adalah peringkat kemampuan membaca siswa Indonesia menurut penelitian Programme for International Student Assessment (PISA) sangat rendah. Peringkat Indonesia pada kategori ini berada di urutan ketiga terbawah dari 41 negara peserta dengan nilai rata-rata 371 pada tahun 2000 dan mengalami peningkatan nilai rata-rata setelah enam tahun kemudian menjadi 393 dan berada di peringkat ke 48 dari 56 negara peserta. Tahun 2009, kemampuan membaca siswa Indonesia ada di peringkat ke 57 dari 65 negara meskipun ada peningkatan nilai rata-rata menjadi 402 , tetapi peringkat ini kembali turun pada tahun 2012 menjadi 60 dari total 65 negara peserta dengan nilai rata-rata 396. Data tersebut menunjukkan kemampuan membaca siswa Indonesia sangat memprihatinkan (Ajisuksmo, 2019: 159).

Untuk mengatasi keadaan tersebut, Kemendikbud membuat aturan berupa Permendikbud No. 23 Tahun 2015 tentang Penumbuhan Budi Pekerti, Pusat Pembinaan, Badan Pengembangan dan Pembinaan Bahasa (Badan Bahasa) dengan Gerakan Literasi Bangsa (GLB) sebagai program unggulannya untuk meningkatkan kemampuan dan minat baca masyarakat yang juga memiliki tujuan untuk menumbuhkan budi pekerti anak melalui budaya literasi (membaca dan menulis). Pengembangan perpustakaan sebagai sumber informasi juga dijadikan salah satu cara menumbuhkan dan meningkatkan gemar membaca (Ajisuksmo, 2019: 160). Menurut Warsihna (2016: 70), meskipun aturan mengenai gerakan literasi bangsa telah dibuat oleh pemerintah, tetapi belum menggembirakan hasilnya karena sampai sekarang kondisi literasi membaca dan menulis masyarakat Indonesia khususnya siswa masih begitu minim.

Sebagai bentuk dukungan masyarakat terhadap pemerintah, mereka turut mendirikan berbagai program penguatan literasi diantaranya kelas penulis cilik yang terdapat di PKBM Ar Rosyid Purwokerto. Kelas penulis cilik adalah program yang memberi pelatihan kepada anak untuk aktif menulis sebuah karya tulis, khususnya cerita pendek. Kegiatan menulis tentu diawali dengan kegiatan banyak membaca. Program ini bertujuan untuk menguatkan kemampuan literasi anak sejak dini. Karena itulah, sangat perlu dilakukan penelitian terhadap program tersebut agar diketahui tingkat efektivitasnya terhadap penguatan literasi anak, yang mana dari penelitian tersebut akan menghasilkan sebuah metode yang berguna bagi perkembangan dan penguatan budaya literasi di Indonesia khususnya bagi anak-anak dan diharapkan dapat dijadikan sebagai salah satu solusi atau jawaban masalah rendahnya minat membaca dan menulis siswa Indonesia yang memerlukan adanya program penguatan literasi.

Penguatan literasi bagi anak-anak tentu membutuhkan metode yang menarik seperti kegiatan-kegiatan yang merangsang minat siswa untuk berliterasi lebih baik seperti program kelas penulis cilik. Untuk itu, penulis melakukan survey terhadap 
peserta program kelas penulis cilik di PKBM Ar Rosyid Purwokerto karena program ini telah menerbitkan dua buah buku antologi cerita anak yang ditulis oleh mereka.

Berdasarkan pemaparan di atas, penelitian ini bertujuan untuk mengetahui efektivitas kegiatan penguatan literasi anak melalui program kelas penulis cilik. Maka muncullah rumusan masalah yaitu bagaimana cara penguatan literasi anak melalui program kelas penulis cilik dan bagaimana mengembangkan program tersebut supaya menjadi solusi dari rendahnya minat membaca siswa Indonesia.

\section{B. METODE}

Penelitian ini menggunakan metode kualitatif deskriptif karena dilakukan pada kondisi alamiah (natural setting) dan bersifat deskriptif (Sugiyono, 2016: 8) di mana penelitian ini menggunakan empat tahap rancangan berupa pra-lapangan, kegiatan lapangan, analisis data, dan penulisan laporan. Tahapan yang pertama adalah pemilihan tempat penelitian dan perizinan, observasi awal dan penyusunan rancangan penelitian serta mempersiapkan perlengkapan yang digunakan selama proses penelitian (Dwi, 2018: 1601). Tahapan berikutnya meliputi observasi, wawancara, angket dan dokumentasi berupa gambar maupun video selama kelas penulis cilik ini berlangsung. Karena antara wawancara dan angket memiliki kelebihan dan kekurangan masing-masing, maka menggunakan gabungan dari kedua cara tersebut akan membawa manfaat yang lebih baik (Keraf, 2004: 182-183). Tahapan ketiga yaitu menganalisis data yang terkumpul di mana sumber data dari lapangan akan dianalisis agar data tersebut dapat disimpulkan sebagai hasil penelitian. Tahap keempat adalah penulisan laporan berupa hasil dari analisis data observasi, wawancara, angket, maupun dokumentasi yang ditulis dalam bentuk laporan penelitian.

Sumber data pada penelitian ini terdiri dari subjek dan objek penelitian. Subjeknya adalah anak-anak yang menjadi peserta program kelas menulis cilik PKBM Ar Rosyid Purwokerto yang berjumlah 20 anak dan lebih khusus pada 3 anak yang masih intens mengikuti program saat penelitian ini dilakukan. Objek penelitian ini adalah kegiatan dalam program kelas penulis cilik. Penelitian ini menggunakan instrumen observasi yang digunakan untuk mengetahui kegiatan program kelas penulis cilik dari awal hingga akhir dalam beberapa pertemuan dan instrumen wawancara atau angket untuk founder program sekaligus tutor pembimbing, peserta, dan wali dari peserta program.

\section{PROGRAM KELAS PENULIS CILIK}

Program kelas penulis cilik PKBM Ar Rosyid berdiri sejak tahun 2018. Tujuan didirikannya kelas penulis cilik adalah menfasilitasi anak-anak yang berminat dalam bidang kepenulisan. Jadwal pembelajaran di kelas penulis cilik dilaksanakan setiap hari Senin pukul 16.00-17.30 wib di PKBM Ar Rosyid Purwokerto. Karena tidak ada batas waktu untuk menjadi maka ada peserta yang mengikuti program selama beberapa bulan saja dan ada yang mengikuti program sampai satu tahun. 
Ketika program kelas penulis cilik baru didirikan, jumlah pesertanya ada lima anak. Beberapa waktu kemudian ada peserta yang keluar dan ada peserta yang masuk dan pernah meningkat jumlahnya menjadi sepuluh anak yang bersama mengikuti program secara intensif. Saat penelitian ini dilakukan, peserta yang masih intens mengikuti program berjumlah tiga anak. jika ditotal telah ada dua puluh anak yang pernah menjadi peserta program ini. Biaya pendidikannya sebesar 50.000 setiap bulannya dan tergolong terjangkau untuk keluarga ekonomi menengah ke atas. Ada pula anak-anak yang mendapat beasiswa berupa pendidikan gratis di kelas penulis cilik selama dua bulan karena naskah cerita mereka terpilih oleh PKBM Ar Rosyid selaku pihak penyelenggara.

Walaupun program ini telah disosialisasikan dari mulut ke mulut, give away, pembuatan poster atau flyer dan melalui media sosial tetapi masih mengalami beberapa kendala yaitu belum adanya tim khusus yang menghandle program sehingga masih harus ditangani sendiri oleh founder. Disisi lain, PKBM Ar Rosyid memiliki banyak program lain dan hal tersebut membuat kurang optimalnya pengelolaan program ini. Kendala lain adalah sedikitnya minat anak-anak untuk mengikuti program ini, terbukti dari 67 penulis yang karyanya di bukukan dalam antologi cerita pendek, baru 29\%nya yang intens mengikuti kelas penulis cilik. Bahkan setelah naskah mereka terpilih dan mendapatkan pendidikan gratis di program ini selama dua bulan tetap belum menambah peserta secara signifikan.

\section{Peserta Kelas Penulis Cilik}

Program ini diperuntukan bagi anak-anak usia SD/MI dan SLTP yang memang memiliki minat dalam bidang tulis menulis. Peserta kelas penulis cilik berusia dari rentang 7 sampai 11 tahun. Mereka merasa senang selama mengikuti program ini karena mendapat teman baru dan dibimbing oleh guru atau tutor yang sabar serta membimbing mereka secara fokus. Selain itu, mereka bisa menggunakan laptop saat menulis juga bisa menerbitkan karya mereka dalam sebuah buku. Peserta telah memiliki kegemaran membaca, menulis, dan bercerita sejak kecil. Ada yang dimulai sejak kelas 1, 2, dan kelas 3 SD yang dibuktikan dengan koleksi buku bacaan yang peserta miliki sudah ada yang berjumlah 90 eksemplar. Buku koleksi peserta kelas penulis cilik jenisnya beragam, mulai dari buku pelajaran, buku cerita, puisi, buku motivasi, antologi, novel, bahkan komik.

Alasan peserta mengikuti program ini karena ingin menerbitkan buku karya sendiri sekaligus mengembangkan pengetahuan, ingin mengetahui tentang cerita dan bagaimana cara membuatnya, ingin menyalurkan hobi, selain itu, dengan menulis dapat menyampaikan kebaikan pada semua orang, walaupun ada yang menjawab karena mendapat sedikit paksaan dari orang tua. Alasan orang tua mengikutsertakan anaknya pada program ini adalah mengembangkan bakat dan kreativitas anak setelah melihat potensi dan kesukaan mereka akan dunia tulis-menulis sekaligus mengurangi intensitas interaksi anak dengan gadget, agar anak memiliki kemampuan menulis yang baik dengan bimbingan yang intensif, dapat menyalurkan hobi anak, dan bagi anak yang 
bersifat tertutup dan susah diajak berdiskusi supaya bisa menuangkan pemikirannya dalam sebuah tulisan.

Sumber inspirasi peserta saat menulis berasal dari pengalaman, bacaan, berita, kisah hidup orang di sekitar mereka, dan kejadian sehari-hari yang mereka alami atau lihat serta dari kegiatan-kegiatan yang dilakukan di kelas penulis cilik. Beberapa kendala yang dihadapi oleh peserta selama kegiatan dan proses menghasilkan karya diantaranya adalah saat intensitas membaca berkurang akan menimbulkan adanya kesulitan untuk memikirkan tema, memikirkan sebuah ide tentang konflik cerita pendek, sulit membuat ide pokok, sulit menentukan judul cerita yang tepat dan merasa kekurangan ide juga sering kurang teliti tentang tanda baca, bahkan timbul rasa malas menulis karena menurunnya motivasi dan kelelahan sebab mengikuti kegiatan ekstrakurikuler yang lain, dan sebagainya.

\section{Bentuk Kegiatan Kelas Penulis Cilik}

Metode pembelajaran yang dilakukan pada program kelas penulis cilik ini menerapkan pemberian teori sebanyak 30\% dan $70 \%$ nya praktik menulis secara langsung. Metode ini bertujuan agar anak-anak dapat membuat karya berupa cerita anak atau cerita pendek serta puisi dengan mengetik langsung di laptop maupun kertas bagi yang belum memiliki komputer. Bentuk kegiatan pembelajaran dalam program ini adalah:

Pertama, peserta dibacakan cerita dari buku atau majalah anak. Kemudian pembimbing menanyai peserta satu per satu tentang isi dari cerita yang telah dibacakan seperti siapa tokohnya dan unsur intrinsik cerita yang lain. Jika telah selesai bertanya dan seluruh peserta telah menjawab, pembimbing memberi teori serta gambaran tentang penulisan sebuah cerita seperti pembuatan judul yang menarik, latihan menggunakan kata dan kalimat yang menarik, penggunaan tanda baca yang benar, serta dilatih cara menggunakan laptop sebelum mulai praktik.

Kedua, praktik dimulai dengan memberikan pertanyaan pancingan seperti "Kegiatan apa saja yang kamu lakukan di sekolah hari ini? Ceritakanlah pengalamanmu." atau "Seperti apa kegiatanmu di rumah?". Setelah peserta terbiasa menuliskan peristiwa, mereka diminta membuat cerita bertema tertentu sesuai yang mereka minati seperti cerita tentang persahabatan, petualangan, fabel, misteri, dan lainlain. Secara abstrak anak-anak akan menuliskan hal yang berbeda dan memunculkan kekhasan terhadap tulisan mereka masing-masing.

Ketiga, pendampingan lebih fokus kepada masing-masing peserta. Pembimbing akan memotivasi sekaligus membimbing mereka melalui kegiatan yang menyenangkan seperti mengajarkan editing dan mengetik di komputer. Setelah praktik selesai kemudian dilakukan evaluasi oleh pembimbing seperti bertanya tentang apa saja kesulitan dan tantangan yang dihadapi oleh peserta. 


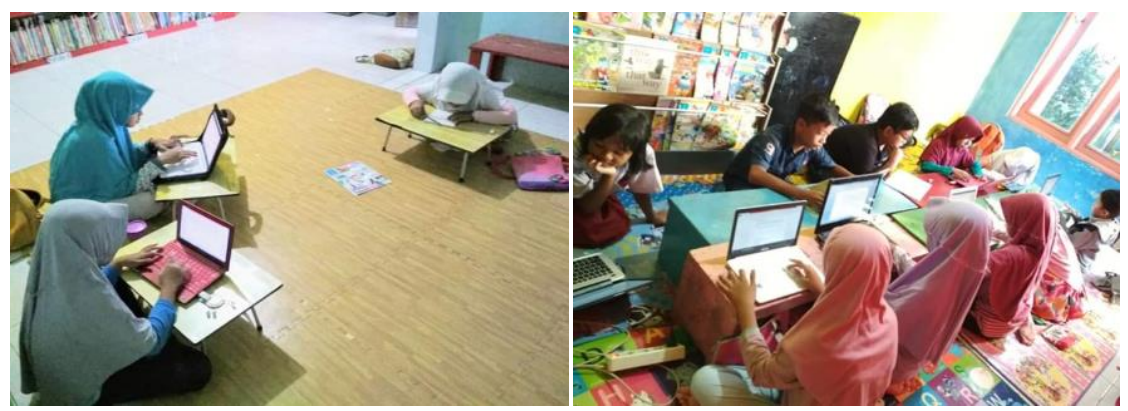

Gambar 1. Kegiatan Kelas Penulis Cilik

\section{Hasil Karya Peserta Kelas Penulis Cilik}

Program ini telah menerbitkan dua buku antologi cerita pendek. Buku pertama berjudul "Camping Persahabatan". Cetakan pertama terbit pada bulan Oktober 2018 dan berisi 33 judul cerita yang ditulis oleh 33 penulis cilik. Beberapa judul cerita di buku ini yaitu "Rumah Pohon Persahabatan", "Misteri Kamar Mandi", "Kejutan untuk Peri Angelina", "Camping Persahabatan", "Trail Adventure", dan lain-lain. Buku kedua berjudul "Petunjuk Tinta Biru" terbit pada Januari 2020 dan berisi 50 judul cerita pendek yang ditulis oleh 50 penulis cilik. Beberapa judul cerita di buku ini adalah "Putri Penolong", "Petunjuk Tinta Biru", "Kakakku Sahabatku”, "Study Tour", "Just Best Friend", dan lain-lain. Keduanya diterbitkan oleh SIP Publishing Banyumas. Jumlah seluruh penulis kedua buku ini ada 67 anak yang berasal dari 20 peserta program kelas penulis cilik dan 47 peserta lomba menulis yang diselenggarakan oleh program ini. Buku ini telah dicetak sebanyak 500 eksemplar dan buku pertamanya telah habis terjual.

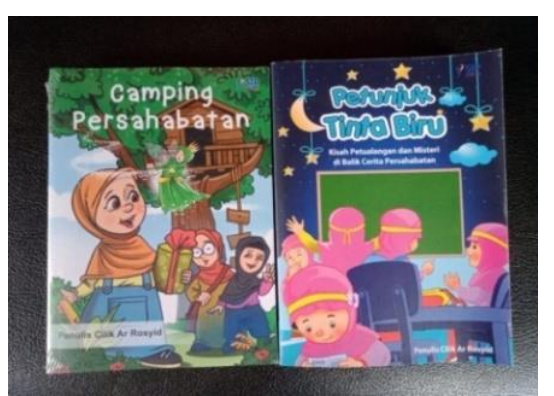

Gambar 2. Buku Antologi Karya Penulis Cilik

\section{FAKTOR PENDUKUNG PENANAMAN BUDAYA LITERASI}

Keberhasilan penanaman dan penguatan literasi anak-anak sejak dini tidak lepas dari peran dan dukungan orang tua (Zati, 2018: 19). Orang tua peserta kelas penulis cilik telah berusaha menanamkan budaya literasi kepada anak mereka. Cara yang ditempuh diantaranya adalah:

1. Memberi dukungan dengan mengenalkan anak yang masih kecil pada buku-buku yang aman untuk dipegang dan digigit baik yang bergambar maupun berwarna mencolok sehingga anak antusias.

2. Sering mendongeng dan membacakan cerita dengan sikap ekspresif sehingga membuat anak selalu meminta dibacakan cerita khususnya sebelum tidur. 
3. Saat anak-anak sudah mulai bisa membaca, orang tua mulai menyediakan buku bacaan di rumah yang diminta oleh anak untuk dibelikan.

4. Memberikan waktu khusus bagi anaknya untuk membaca dan menulis dengan membiasakan anak menuliskan pengalamannya.

5. Memotivasi anak jika mood menulisnya menurun melalui berbagai kegiatan seperti mengajak mereka berkunjung ke perpustakaan daerah atau museum.

6. Berdiskusi tentang kesulitan yang dirasakan anak selama menulis dan mengapresiasi karya mereka.

7. Mengingatkan, mengantar jemput dan memfasilitasi keperluan anak selama mengikuti program penguatan literasi.

8. Memberikan teladan membaca kepada anak. Jumlah koleksi buku bacaan orang tua peserta kelas penulis cilik ada yang telah mencapai 400 dan 800 eksemplar. Beberapa orang tua bahkan bekerja sebagai pustakawan.

Orang tua berharap dengan adanya penguatan literasi melalui program ini membuat anak-anak bisa menemukan jati diri, lebih terasah bakat menulisnya dan semakin benar penulisannya, dapat lebih terbuka kepada orang lain, mampu mengaplikasikan keinginannya dengan usaha maksimal, dan lebih bersemangat supaya lebih produktif dalam menulis sehingga dapat menerbitkan karya-karya mereka.

\section{E. PROGRAM KELAS PENULIS CILIK SEBAGAI SARANA PENGUATAN LITERASI ANAK}

Program kelas penulis cilik ini sangat membantu dan berkaitan erat dengan penguatan literasi. Program ini membuat peserta mampu menulis cerita anak, mengembangkan ide, mengemas pesan karakter ke dalam sebuah cerita dan lebih memahami tulisan serta dapat mendeskripsikan maksud dan tujuan yang ada dalam tulisan. Penguatan literasi harus dilakukan sejak dini dan melalui program ini akan semakin banyak anak-anak yang mampu menghasilkan karya dan memiliki prestasi lewat tulisan mereka karena program ini memberikan bimbingan secara intensif terhadap peserta.

Manfaat yang dirasakan oleh peserta setelah mengikuti program ini, diantaranya adalah:

1. Lebih bahagia dan nyaman saat menulis.

2. Lebih mudah memahami hikmah suatu kejadian.

3. Lebih mudah menggali ide jika diminta guru untuk tugas menulis.

4. Setelah membaca dapat memperoleh informasi dan menambah kosakata.

5. Adanya perkembangan mental dan cara pandang sehingga lebih peka dan mudah menerima kebaikan.

6. Berkembang pengetahuan dan pemahaman membuat lebih bisa bersikap terbuka dan percaya diri.

7. Memperoleh prestasi di bidang literasi. Prestasi yang telah diraih peserta diantaranya adalah karya yang sudah diterbitkan di buku antologi cerita anak, juara lomba menulis syair, juara lomba menulis cerpen, juara menulis cerita anak, dan juara lomba mental aritmatika. 
Kelebihan dari program ini adalah dapat memfasilitasi anak-anak dan membantu meningkatkan kemampuan mereka di bidang literasi, peserta lebih berinteraksi dan bersemangat karena memasuki komunitas, waktu pembelajaran efisien, biaya program yang terjangkau, lokasinya strategis, serta memiliki kegiatan yang bervariasi, menyenangkan dan sesuai dengan pola pikir anak.

Kekurangan dari program ini adalah kurang optimalnya pengelolaan program karena kekurangan tutor atau pembimbing, baru dapat memfasilitasi anak-anak yang telah memiliki minat dalam bidang literasi saja, dan belum menyediakan fasilitas komputer untuk anak yang belum memilikinya dan menyebabkan adanya kesenjangan antar peserta.

\section{F. SIMPULAN}

Berdasarkan uraian di atas dapat disimpulkan bahwa program kelas penulis cilik efektif merupakan salah satu sarana penguatan literasi anak-anak karena dapat menarik perhatian anak-anak sehingga mereka dapat melakukan kegiatan literasi dengan menyenangkan dan terbukti peserta merasakan manfaat dan dapat menghasilkan karya. Budaya literasi yang telah ditanamkan orang tua di lingkungan rumah mendapatkan penguatan dengan adanya program ini.

Metode pembelajaran dalam kelas penulis cilik diawali dengan kegiatan menceritakan cerita anak kepada peserta. Selanjutnya menanyakan unsur intrinsik cerita pada peserta baru kemudian mendemonstrasikan tata cara menulis cerita yang dilanjutkan dengan memberi umpan kepada peserta untuk menulis dan mempraktikan pembuatan cerita disertai kegiatan menyenangkan seperti editing. Kegiatan terakhir berupa pendampingan terhadap masing-masing peserta secara lebih intensif.

\section{DAFTAR PUSTAKA}

Ajisuksmo, Clara R.P, at.al. 2019. "Pelatihan Kerajinan Decoupage Sebagai Cara untuk Menumbuhkan Budaya Literasi Kaum Perempuan" dalam Jurnal Abdimas Dewantara edisi Vol. 2, No. 2, 158-170.

Dikdasmen. 2016. Panduan Gerakan Literasi Sekolah. Jakarta: Kemendikbud.

Keraf, Gorys. 2004. Komposisi. Semarang: Bina Putera.

Mangesti P.R Dwi dan Heru Subrata. 2018. "Penggunaan Media Gamelan Sederhana dalam Pembelajaran Tembang Dolanan di Kelas IV SDN Sumur Welut 1 Surabaya". Jurnal PGSD. Vol. 06, No. 09, 1599-1609.

Priyatni, E. T. 2015. Desain Pembelajaran Bahasa Indonesia dalam Kurikulum 2013. Jakarta: PT Bumi Aksara.

Safitri, Laela, at.al. 2019. "Pengaruh Membaca 15 Menit Terhadap Minat Baca Siswa Sekolah Dasar”. Jurnal Cakrawala Pendas. Vol. 5 No. 2, 153-157.

Sugiyono. 2016. Metode Penelitian Pendidikan Pendekatan Kuantitatif, Kualitatif dan $R \& D$. Bandung: ALFABETA. 
Tarigan, H.G. 2015. Membaca Sebagai Suatu Keterampilan Berbahasa. Bandung: Angkasa.

Warsihna, Jaka. 2016. "Meningkatkan Literasi Membaca dan Menulis dengan Teknologi Informasi dan Komunikasi (TIK)". Jurnal Kwangsan. Vol. 4 No. 2, 67-80.

Zati, Vidya A.D. 2018. "Upaya untuk Meningkatkan Minat Literasi Anak Usia Dini”. Jurnal Bunga Rampai Usia Emas. Vol. 4 No. 1, 18-21. 